\title{
The resemblance and disparity of gene expression in dormant and non-dormant seeds and crown buds of leafy spurge (Euphorbia esula)
}

\author{
Wun S Chao*, Münevver Doğramaci, James V Anderson, Michael E Foley and David P Horvath
}

\begin{abstract}
Background: Leafy spurge (Euphorbia esula L.) is a herbaceous perennial weed and dormancy in both buds and seeds is an important survival mechanism. Bud dormancy in leafy spurge exhibits three well-defined phases of para-, endo- and ecodormancy; however, seed dormancy for leafy spurge is classified as physiological dormancy that requires after-ripening and alternating temperature for maximal germination. Overlaps in transcriptome profiles between different phases of bud and seed dormancy have not been determined. Thus, we compared various phases of dormancy between seeds and buds to identify common genes and molecular processes, which should provide new insights about common regulators of dormancy.

Results: Cluster analysis of expression profiles for 201 selected genes indicated bud and seed samples clustered separately. Direct comparisons between buds and seeds are additionally complicated since seeds incubated at a constant temperature of $20^{\circ} \mathrm{C}$ for 21 days ( $21 \mathrm{~d} \mathrm{C}$ ) could be considered paradormant (Para) because seeds may be inhibited by endosperm-generated signals, or ecodormant (Eco) because seeds germinate after being subjected to alternating temperature of $20: 30^{\circ} \mathrm{C}$. Since direct comparisons in gene expression between buds and seeds were problematic, we instead examined commonalities in differentially-expressed genes associated with different phases of dormancy. Comparison between buds and seeds ('Para to Endo buds' and '21d C to 1d C seeds'), using endodormant buds (Endo) and dormant seeds (1d C) as common baselines, identified transcripts associated with cell cycle (HisH4), stress response/transcription factors (ICE2, ERFB4/ABR1), ABA and auxin response (ABA1, ARF1, IAA7, TFL1), carbohydrate/protein degradation (GAPDH_1), and transport (ABCB2). Comparison of transcript abundance for the 'Eco to Endo buds' and '21d C to $1 \mathrm{~d} C$ seeds' identified transcripts associated with ABA response (ATEM6), auxin response (ARF1), and cell cycle (HisH4). These results indicate that the physiological state of $21 \mathrm{~d} \mathrm{C}$ seeds is more analogous to paradormant buds than that of ecodormant buds.

Conclusion: Combined results indicate that common molecular mechanisms associated with dormancy transitions of buds and seeds involve processes associated with ABA and auxin signaling and transport, cell cycle, and AP2/ERF transcription factors or their up-stream regulators.
\end{abstract}

Keywords: Leafy spurge, Bud dormancy, Seed dormancy, Gene expression, Hormones, Transcription factors

\footnotetext{
* Correspondence: wun.chao@ars.usda.gov

USDA-Agricultural Research Service, Biosciences Research Lab, Sunflower and

Plant Biology Research Unit, 1605 Albrecht Boulevard N, Fargo, ND 58102,

USA
}

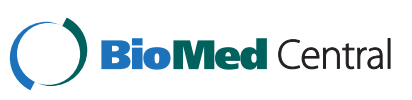

(c) 2014 Chao et al.; licensee BioMed Central Ltd. This is an Open Access article distributed under the terms of the Creative Commons Attribution License (http://creativecommons.org/licenses/by/4.0), which permits unrestricted use, distribution, and reproduction in any medium, provided the original work is properly credited. The Creative Commons Public Domain Dedication waiver (http://creativecommons.org/publicdomain/zero/1.0/) applies to the data made available in this article, unless otherwise stated. 


\section{Background}

Leafy spurge (Euphorbia esula L.) is considered an invasive perennial weed in the Upper Great Plains of North America and has been reported to cause significant economic losses [1]. Vegetative reproduction from an abundance of underground adventitious buds (often referred to as crown and root buds) and sexual reproduction through seeds allow leafy spurge to persist and spread. Dormancy in both buds and seeds is an important survival mechanism for leafy spurge and many other invasive perennial weeds. In leafy spurge, seed dormancy ensures distribution of germination in time and space, whereas bud dormancy inhibits underground adventitious buds from initiating new vegetative growth.

Dormancy classifications are different between bud and seed. In seeds, dormancy is defined as a developmental state in which germination fails under favorable environmental conditions [2]. Seed dormancy is also determined by both morphological and physiological properties [3-5]. Seed dormancy for leafy spurge is classified as physiological dormancy, which varies between populations from little or no dormancy to moderate periods of dormancy [6,7]. Physiological dormancy in leafy spurge generally can be released by cold or warm stratification. However, dormant leafy spurge seeds do not germinate at constant temperatures of $20^{\circ} \mathrm{C}$ or $30^{\circ} \mathrm{C}$, but imbibing seeds for 21 days at constant temperature $\left(20^{\circ} \mathrm{C}\right)$ followed by an alternating temperature $\left(20: 30^{\circ} \mathrm{C}\right)$ treatment increases germination to over $60 \%$ in 10 days [8].

Bud dormancy is subdivided into the three welldefined phases of para-, endo-, and eco-dormancy. Paradormancy (Para) is growth cessation controlled by physiological factors external to the affected structure, endodormacy (Endo) is growth cessation controlled by internal physiological factors, and ecodormancy is growth cessation controlled by external environmental factors [9]. Paradormancy in leafy spurge inhibits buds from developing into new shoots through signals such as auxin and sugars generated from the actively growing aerial portion of the plant [10-12], whereas endodormancy is triggered by cold temperature and short photoperiods in autumn [13-15]. Endodormancy is released, and ecodormancy (Eco) is maintained, by extended cold.

Seed and bud dormancy appears to involve similar physiological processes as both require abscisic acid (ABA) to induce dormancy and gibberellins (GA) to break dormancy, and both accumulate similar reserve proteins and lipids during dormancy [16,17]. Chilling has also been reported to break dormancy in seeds and buds of some species $[18,19]$. It has been suggested that some common mechanisms may regulate both seed and bud dormancy [20]. We also hypothesized that common mechanisms likely overlap in regulation of dormancy in buds and seeds of leafy spurge.
Although phenotypic analysis of mutants or transgenic plants is a primary strategy to understand the function/ role of plant regulators (genes or hormones), the strategy is not often suitable for plants difficult to perform these alterations as in the case of leafy spurge. Comparative transcriptome analysis on buds and seeds is a good complement and would assist in the identification of conserved cell processes and important expression programs that are difficult to achieve using mutagenesis or transgenic approaches. Leafy spurge is a model perennial to investigate both seed and bud dormancy $[12,15,21,22]$, and these investigations have identified a subset of genes involved in regulation of growth and development. Thus, in this study, the objectives are to identify commonalities in differentially-expressed genes, common trends in gene expression, and general molecular mechanisms during bud and seed dormancy and its release. Identification of common molecular processes regulating dormancy in seeds and buds in leafy spurge should provide new insights about common regulators of dormancy induction and release.

\section{Results and discussion}

Quantitative real time - polymerase chain reaction (qRT-PCR)

This study compared various phases of dormancy between crown buds (designated as "buds" throughout the text) and seeds using physiologically analogous dormancy conditions based on information obtained through previous dormancy studies in leafy spurge buds and seeds. Two hundred and one leafy spurge homologs of Arabidopsis genes involved in growth, hormone, light, and temperature response/regulation were selected for analysis (Additional file 1: Table S1). Gene expression by qRT-PCR was examined using total RNA prepared from seed and bud samples. Although all 201 primer pairs were designed based on sequences obtained from a leafy spurge ESTdatabase (for details, see $M \& M$ ), the possibility exists for different paralogues and alleles of target genes being amplified by a given primer pair. For this reason, we examined all the amplicons in the form of melting point curves (melting point temperatures; $\mathrm{Tm}$ ) and visualization by gel electrophoresis (see Additional file 2: Table S2) for each of our primer pairs. The results indicated that the majority of these amplicons are unique. Among 201 genes, only 15 showed $>$ one melting point curve (with $2 \mathrm{Tm}$ values). However, our results showed that melting curve analysis alone was insufficient to recognize all specific/nonspecific amplification; for example, COP1 (Primer \# MD-041, lane 62) was observed as a single amplicon in agarose gel, but dissociation analysis generated two melting point curves (see melting point curves of these two genes in Additional file 2: Table S2). Since other factors such as G/C rich, amplicon misalignment in $\mathrm{A} / \mathrm{T}$ rich regions, and secondary structure in the amplicon region can cause melting 
of DNA molecules in multiple phases [23], gel visualization of DNA bands is needed to accurately diagnose the number and size of amplicons.

Interestingly, some of the non-unique amplicons showed a migration in amplicon sizes under different phases of dormancy or in different organs; for example, DREB A-1/DREB1D (Primer \# 598, agarose gel lane 44) was expressed as a single amplicon in all samples except endodormant buds (Endo), and ATSR1 (Primer \# 609, agarose gel lane 46) was expressed as a single amplicon in $1 \mathrm{~d} \mathrm{C}$ and $21 \mathrm{~d} \mathrm{C}$ seeds but as double amplicons in all other samples (see melting point curves of these two genes in Additional file 2: Table S2). Therefore even if the multiple products are amplified by a given primer pair, the differential accumulation of transcripts from a given gene family still indicate their response to physiological processes associated with comparable phases of dormancy.

\section{Cluster analysis}

Cluster analysis on the expression profiles of 201 genes (Additional file 1: Table S1) indicated that buds and seeds fell into two main groups (Figure 1). One group contained all bud samples (Figure 2); Eco, Endo, Para, and 2dgrowth (after paradormancy release). The second group contained all seed samples (Figure 3); 1d C (dormant), 21d $\mathrm{C}+2 \mathrm{~d}$ A (germinating), and 21d C (germination competent but inhibited by environmental or physiological signals). Even though buds and seeds clustered separately (Figure 1), it is possible that common physiological processes associated with dormancy states exist between them. For example, although $2 \mathrm{~d}$-growth and $21 \mathrm{~d} C+2 \mathrm{~d} A$ both contained growing meristems, this similarity did not make these two samples cluster together.

These results suggest that substantial transcriptomic divergence may exist between buds and seeds, which could be due to differences in tissue types or other physiological, developmental, or environmental states. Consequently, direct comparison between buds and seeds was difficult. To overcome this barrier, we selected two common baselines to determine trends in differentially-expressed genes and identify common processes between analogous dormancy phases of buds and seeds. The endodormant phase was used as the baseline for buds, whereas $1 \mathrm{~d} C$ (dormant) was used as the baseline for seeds.

The physiological state of $21 \mathrm{~d} \mathrm{C}$ seeds is more analogous to paradormant buds than that of ecodormant buds

Seeds incubated for 1 day at the constant temperature of $20^{\circ} \mathrm{C}(1 \mathrm{~d} \mathrm{C})$ will not germinate at optimal growth conditions; however, seeds incubated at a constant temperature of $20^{\circ} \mathrm{C}$ for 21 days $(21 \mathrm{~d} \mathrm{C}$ ) will germinate when subjected to alternating temperatures of $20: 30^{\circ} \mathrm{C}$ [8] (see also Figure 3). Thus, the physiological state of $21 \mathrm{~d} \mathrm{C}$ seeds

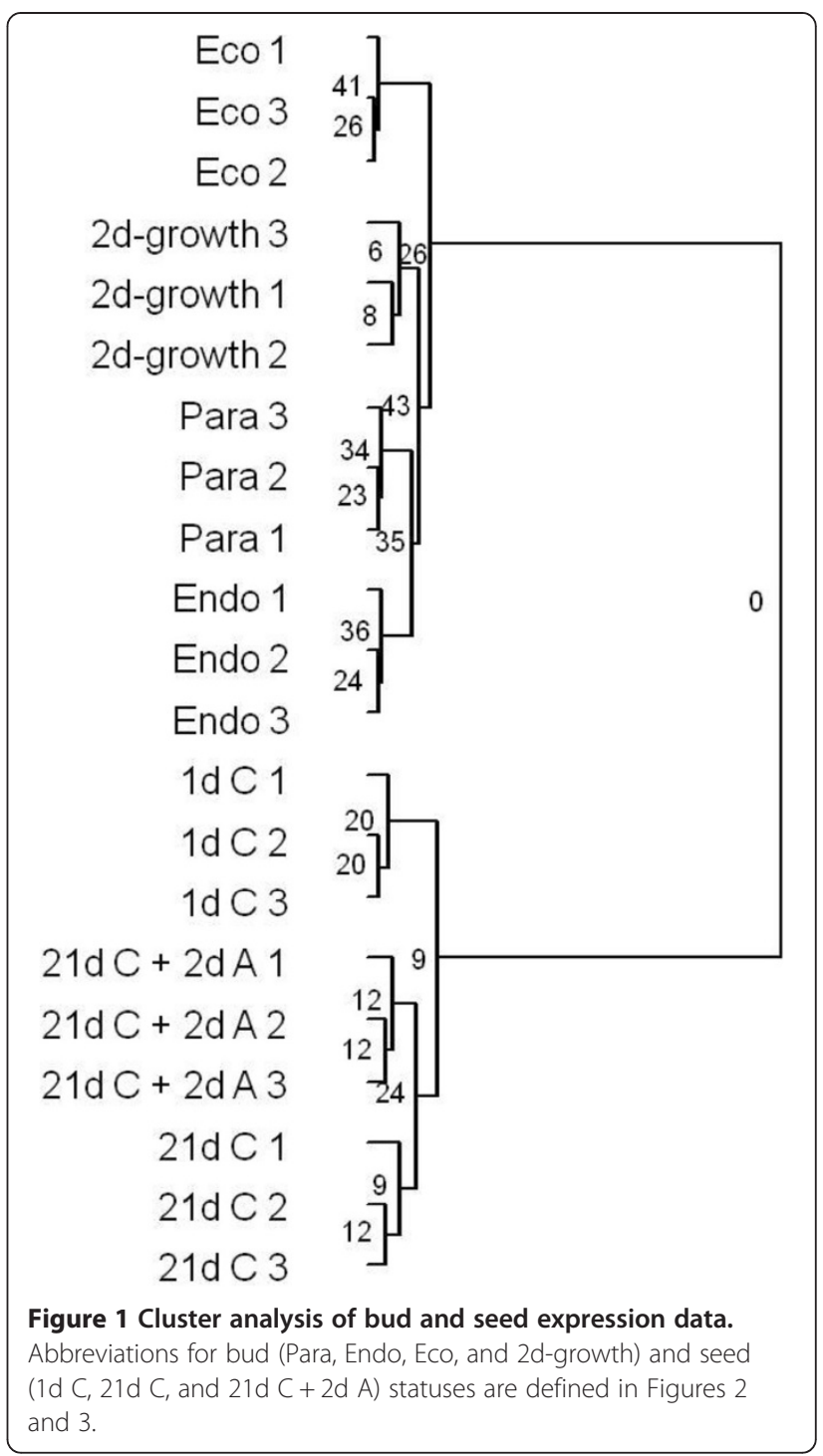

could be comparable to paradormant buds if seed germination was inhibited by endosperm-generated signals. In contrast, the physiological state of $21 \mathrm{~d} C$ seeds could also be comparable to ecodormant buds if seed germination was inhibited by mechanisms such as a requirement for diurnal temperature variation. Neither endodormant buds nor $1 \mathrm{~d} C$ seeds will germinate at optimal growth conditions and, for reasons mentioned above, they were used as common baselines for buds and seeds, respectively. We first determined differentially-regulated genes within buds (i.e., 'Para to Endo' or 'Eco to Endo') and seeds (i.e., '21d C to $1 \mathrm{~d} \mathrm{C}^{\prime}$ ) for the 201 genes by qRT-PCR (Additional file 1 : Table S1). Transcript abundance for 48, 29, and 64 genes was significantly different $(\mathrm{p}<0.1)$ in 'Para to Endo, 'Eco to Endo', and ' $21 \mathrm{~d} \mathrm{C}$ to $1 \mathrm{~d}$ C' comparisons, respectively (Additional file 3: Table S3). Common differentiallyexpressed genes were then identified based on the following comparisons: (1) paradormant buds vs. growth- 
competent seeds ('Para to Endo' vs. '21d C to $1 \mathrm{~d}$ C'), and (2) ecodormant buds vs. growth-competent seeds ('Eco to Endo' vs. '21d C to $1 \mathrm{~d} C$ ') (Tables 1 and 2).

Comparison of transcript expression profiles between 'Para to Endo' buds and '21d C to 1d C' seeds identified 15 common differentially-expressed genes (Table 1).
Some transcript changes were significant but not large in amplitude. Nine of these genes showed the same trend in expression pattern. These 9 transcripts are involved in ABA biosynthesis $(A B A 1)$, auxin transport or response ( $A B C B 2, I A A 7 / A X R 2, A R F 1)$, ethylene response (ERF B-4/ $A B R 1)$, carbohydrate/protein degradation (GAPDH_1),

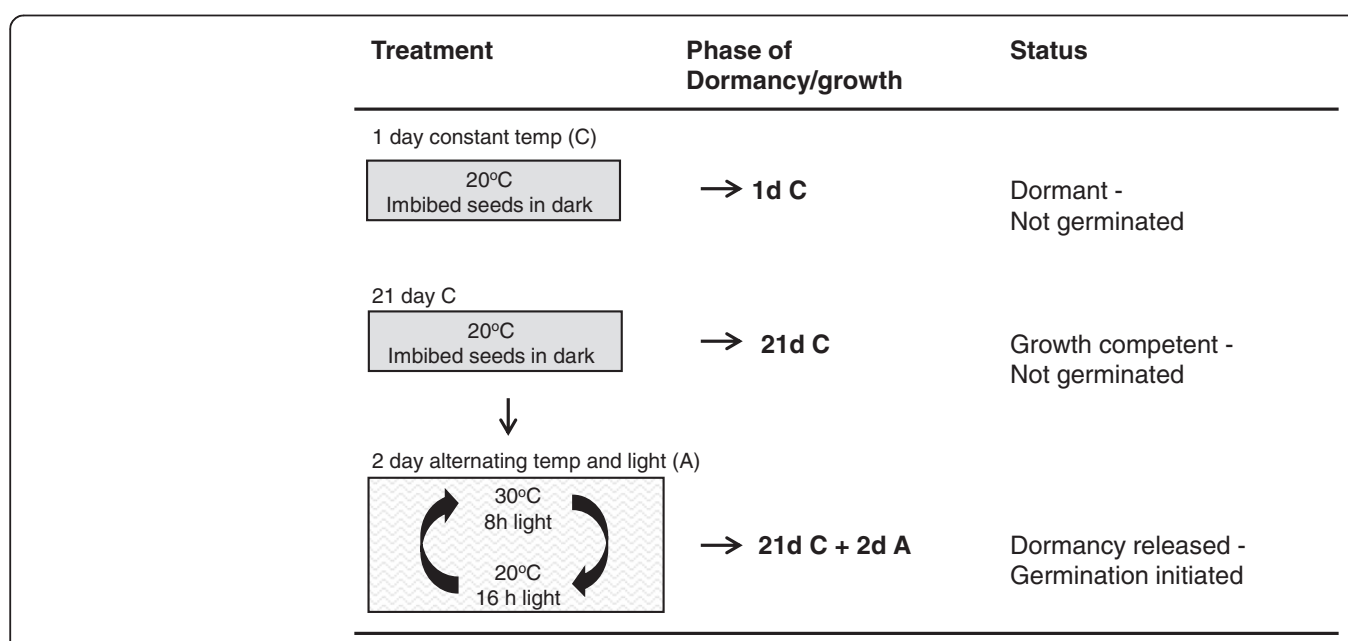

Figure 3 Treatments abbreviations and seed status for qRT-PCR analysis. 
Table 1 Fold changes were represented by positive and negative fold numbers

\begin{tabular}{|c|c|c|c|c|}
\hline Process & Gene & TAIR ID & $\frac{\text { Fold change }}{\text { ('Para to Endo') }}$ & $\frac{\text { Fold change }}{\left.\text { ('21d } C \text { to } 1 d C^{\prime}\right)}$ \\
\hline \multicolumn{5}{|l|}{$\mathrm{ABA}$} \\
\hline ABA biosynthesis & $A B A 1$ & At5g67030 & $-2.50^{*}$ & $-1.81^{*}$ \\
\hline \multicolumn{5}{|l|}{ Auxin } \\
\hline $\mathrm{ABC}$ transporter & $A B C B 2$ & At4g25960 & $-2.74^{* *}$ & $-2.92^{* *}$ \\
\hline Auxin AUX/IAA & IAAT/AXR2 & At3g23050 & $-4.98^{* *}$ & $-2.78^{*}$ \\
\hline Auxin response & ARF1 & At1g59750 & $-1.68^{*}$ & $-2.73^{* *}$ \\
\hline \multicolumn{5}{|l|}{ Cytokinin } \\
\hline Cytokinin catabolic process & CKX5 & At1g75450 & $4.45^{*}$ & $-3.53^{*}$ \\
\hline \multicolumn{5}{|l|}{ Gibberellic acid } \\
\hline GA response - receptor & GID1B & At3g63010 & $5.79^{* *}$ & $-1.54^{*}$ \\
\hline \multicolumn{5}{|l|}{ Ethylene } \\
\hline \multirow[t]{2}{*}{ AP2/ERF TF } & ERF B-3/ERF1 & At4g17500 & $6.16^{*}$ & $-8.42^{* *}$ \\
\hline & ERF $B-4 / A B R 1$ & At5g64750 & $-5.21^{* *}$ & $-16.0^{* *}$ \\
\hline Ethylene response - receptor & ETR2 & At3g23150 & $2.31^{*}$ & $-4.09 * *$ \\
\hline \multicolumn{5}{|l|}{ Miscellaneous } \\
\hline Carbohydrate/protein degradation & GAPDH_1 & At1g13440 & $-5.39^{* *}$ & $-5.18^{* *}$ \\
\hline Cell cycle & Histone H4 & At1g07660 & $-2.00^{* *}$ & $-3.15^{*}$ \\
\hline Flowering & TFL1 & At1g18100 & $-1.74^{*}$ & $-8.27^{*}$ \\
\hline Phosphorylation & MKK9 & At1g73500 & $2.99^{*}$ & $-2.25^{*}$ \\
\hline \multirow[t]{2}{*}{ Stress response } & ICE2 & At1g12860 & $-2.24^{* *}$ & $-2.77^{* *}$ \\
\hline & LEA 4-5 & At5g06760 & $0.20^{* *}$ & $-11.1^{* *}$ \\
\hline
\end{tabular}

Fold changes for buds were determined by comparing the gene expression of paradormant buds to endodormant buds ('Para to Endo'), and fold changes for seeds were determined by comparing the gene expression of 21-day $C$ seeds to 1-day $C$ seeds ('21d $C$ to $1 \mathrm{~d} C^{\prime}$ ). Common genes were then identified between buds and seeds. The Arabidopsis Information Resource (TAIR) IDs represent Arabidopsis genes used to annotate homologues of leafy spurge transcripts. Unpaired two-sample t-tests were performed; symbol "*" represents genes at a p-value $<0.1$, and "**" represents genes at a $\mathrm{p}$-value $<0.05$.

cell cycle (Histone H4), flowering (TFL1), and stress response (ICE2). Six showed an opposite trend in expression pattern and are involved in cytokinin catabolic process $(C K X 5), \mathrm{GA}$ response (GID1B), ethylene response (ERF $B-3 / E R F 1, E T R 2)$, phosphorylation (MKK9), and stress response (LEA 4-5).

The ABA biosynthetic gene $A B A 1$ was among those showing the same trend in expression pattern. This gene was down-regulated in both paradormant buds and 21d C seeds relative to endodormant buds and $1 \mathrm{~d} C$ seeds, respectively. $A B A 1$ encodes zeaxanthin epoxidase which plays a role in the epoxidation of zeaxanthin to antheraxanthin and all-trans-violaxanthin in the ABA biosynthetic pathway. $A B A 1$ expression was significantly lower in the ABA deficient mutant (aba1) than those in wild-type Arabidopsis; in addition, exogenous ABA application enhanced the expression of $A B A 1$ significantly [24]. Therefore, the down-regulation of $A B A 1$ could indicate that ABA synthesis was lower in paradormant buds and 21d C seeds relative to endodormant buds and $1 \mathrm{~d} C$ seeds. Genes involved in auxin transport $(A B C B 2)$ and response (IAA7/ $A X R 2, A R F 1)$ were also down-regulated in paradormant buds and 21d $\mathrm{C}$ seeds. $A B C B 2$ encodes p-glycoprotein (PGP) and facilitates the cellular and long-distance transport of auxin [25]. Both $I A A 7 / A X R 2$ and $A R F 1$ are auxinresponsive genes. In general, the transcription factor ARF proteins bind to the promoters of auxin-responsive genes to activate or repress transcription. IAA7/AXR2 encodes an Aux/IAA protein which is a transcriptional regulator that represses transcription controlled by ARF [26,27]. The down-regulation of $A B C B 2, I A A 7 / A X R 2$, and $A R F 1$ suggested that there may be lower auxin signaling in paradormant buds and $21 \mathrm{~d} C$ seeds relative to their baseline.

Comparison of transcript expression profiles between 'Eco to Endo' buds and '21d C to $1 \mathrm{~d}$ C' seeds identified 10 common differentially-expressed genes (Table 2). Similar to 'Para to Endo' and '21d C to 1d C' comparison, some of their transcript changes were not large in amplitude. Among the10 common genes, only three showed the same trend in expression pattern. These 3 transcripts are involved in ABA response (ATEM6), auxin response (ARF1), and cell cycle (Histone H4). Seven showed an opposite trend in expression pattern and are involved in ABA response $(A B I 1)$, auxin response or transport (GH3.1 RUB1, 
Table 2 Fold changes were represented by positive and negative fold numbers

\begin{tabular}{|c|c|c|c|c|}
\hline Process & Gene & TAIR ID & $\frac{\text { Fold change }}{\text { ('Eco to Endo') }}$ & $\frac{\text { Fold change }}{\left.\text { ('21d } C \text { to } 1 d C^{\prime}\right)}$ \\
\hline \multicolumn{5}{|l|}{$\overline{A B A}$} \\
\hline \multirow[t]{2}{*}{ ABA response } & $A B / 1$ & At4g26080 & $1.46^{*}$ & $-4.54^{* *}$ \\
\hline & ATEM6 & At2g40170 & $-4.79^{*}$ & $-7.69^{* *}$ \\
\hline \multicolumn{5}{|l|}{ Auxin } \\
\hline \multirow[t]{3}{*}{ Auxin response } & ARF1 & At1g59750 & $-1.68^{*}$ & $-2.73^{* *}$ \\
\hline & GH3.1 & At2g14960 & $1.84^{*}$ & $-2.78^{* *}$ \\
\hline & $R \cup B 1$ & At1g31340 & $1.56^{*}$ & $-2.50^{* *}$ \\
\hline Auxin AUX/IAA & IAA16 & At3g04730 & $2.06^{*}$ & $-4.35^{*}$ \\
\hline Auxin transporter & PILS7 & At5g65980 & $2.43^{*}$ & $-11.0^{* *}$ \\
\hline \multicolumn{5}{|l|}{ Cytokinin } \\
\hline Cytokinin catabolic process & $C K X 5$ & At1g75450 & $3.06^{*}$ & $-3.53^{*}$ \\
\hline \multicolumn{5}{|l|}{ Miscellaneous } \\
\hline Cell cycle & Histone H4 & At1g07660 & $-1.84^{* *}$ & $-3.15^{*}$ \\
\hline Stress response & LEA 4-5 & At5g06760 & $8.16^{*}$ & $-11.1^{* *}$ \\
\hline
\end{tabular}

Fold changes for buds were determined by comparing the gene expression of ecodormant buds to endodormant buds ('Eco to Endo'), and fold changes for seeds were determined by comparing the gene expression of 21-day $C$ seeds to 1-day $C$ seeds ('21d $C$ to $1 \mathrm{~d} C^{\prime}$ ). Common genes were then identified between buds and seeds. The Arabidopsis Information Resource (TAIR) IDs represent Arabidopsis genes used to annotate homologues of leafy spurge transcripts. Unpaired two-sample t-tests were performed; symbol "**" represents genes at a p-value $<0.1$, and "**" represents genes at a $p$-value $<0.05$.

IAA16, PILS7), cytokinin catabolic process (CKX5), and stress response (LEA 4-5).

The ABA responsive gene ATEM6 and auxin responsive gene $A R F 1$ exhibited a similar down-regulated trend in expression pattern in ecodormant buds and 21d $\mathrm{C}$ seeds relative to endodormant buds and $1 \mathrm{~d} C$ seeds, respectively. ATEM6 is ABA-inducible and is expressed primarily in the shoot apical meristem and provascular tissue [28]. ATEM6 encodes a group 1 LEA protein which may contribute to cellular stability within the desiccated seed. The down-regulation of ATEM6 and ARF1 suggested that there may be lower ABA and auxin signaling in ecodormant buds and $21 \mathrm{~d} C$ seeds. Though this may be true for 21d C seeds, such conclusion may not apply to ecodormant buds as other ABA responsive $(A B I 1)$ and auxin responsive $(G H 3.1, R U B 1)$ genes were slightly up-regulated. Overall, based on the number of genes and their trend in gene expression, the physiological state of $21 \mathrm{~d} C$ seeds is more analogous to paradormant buds than that of ecodormant buds.

\section{Growth initiation induced auxin response/transport and cell expansion processes in both buds and seeds}

Growth-induced buds (Figure 2) were compared with germination-induced seeds (Figure 3) to identify analogous physiological responses during the initial phase of bud and seed growth. We first determined differentiallyexpressed genes within buds (i.e., '2d-growth to Endo') and seeds (i.e., ' $21 \mathrm{~d} C+2 \mathrm{~d} A$ to $1 \mathrm{~d} C$ ') for the 201 genes
(Additional file 1: Table S1). Transcript abundance for 23 and 35 genes was significantly different $(\mathrm{p}<0.1)$ in '2d-growth to Endo' and ' $21 \mathrm{~d} C+2 \mathrm{~d}$ A to $1 \mathrm{~d}$ C' comparisons, respectively (Additional file 3: Table S3). Comparison of buds and seeds (i.e., '2d-growth to Endo' vs. '21d $\mathrm{C}+2 \mathrm{~d}$ A to $1 \mathrm{~d} \mathrm{C}^{\prime}$ ) identified 6 common differentiallyexpressed genes (Table 3), of which 3 had the same trend in expression. These 3 transcripts are involved in auxin transport (PID, PIN3) and growth (EXP6). The other 3 showed an opposite trend in expression pattern and are involved in auxin transport (PILS7), cytokinin catabolism (CKX5), and amino acid biosynthesis (SK1).

Transcript of PID and PIN3 were up-regulated in both $2 \mathrm{~d}$-growth buds and $21 \mathrm{~d} \mathrm{C}+2 \mathrm{~d} A$ seeds relative to endodormant buds and $1 \mathrm{~d} \mathrm{C}$ seeds, respectively. These two genes are involved in asymmetric auxin distribution for the gravitropic response [29]. In addition, transcript of EXP6 was up-regulated in 2d-growth buds and 21d $\mathrm{C}+2 \mathrm{~d}$ A seeds. EXP6 is involved in the modulation of cell wall extensibility [30] and leaf growth [31]. Given the roles of PID, PIN3, and EXP6 in various aspects of growth, the up-regulation of these genes, not surprisingly, imply similar processes are involved in initial stages of growth in both buds and seeds.

MAF3 displayed $>10$-fold transcript abundance at specific phases of dormancy/growth

Genes that had large changes in transcript abundance (>10-fold) may reflect specific roles during various phases 
Table 3 Fold changes were represented by positive and negative fold numbers

\begin{tabular}{|c|c|c|c|c|}
\hline & & & Fold change & Fold change \\
\hline Process & Gene & TAIR ID & ('2d-growth to Endo') & $\left({ }^{\prime} 21 d C+2 d A\right.$ to $\left.1 d C^{\prime}\right)$ \\
\hline \multicolumn{5}{|l|}{ Auxin } \\
\hline \multirow[t]{3}{*}{ Auxin transporter } & PID & At2g34650 & $1.30^{*}$ & $2.96^{* *}$ \\
\hline & PILS7 & At5g65980 & $3.04^{*}$ & $-10.0^{* *}$ \\
\hline & PIN3 & At1g70940 & $2.01^{*}$ & $4.15^{*}$ \\
\hline \multicolumn{5}{|l|}{ Cytokinin } \\
\hline Cytokinin catabolic process & CKX5 & At1g75450 & $8.11^{*}$ & $-3.42^{* *}$ \\
\hline \multicolumn{5}{|l|}{ Miscellaneous } \\
\hline Amino acid biosynthesis & SK1 & At2g21940 & $2.67^{* *}$ & $-2.20^{*}$ \\
\hline Growth & EXP6 & At2g28950 & $2.06^{*}$ & $19.0^{* *}$ \\
\hline
\end{tabular}

Fold changes for buds were determined by comparing the gene expression of $2 \mathrm{~d}$-growth buds to endodormant buds ('2d-growth to Endo'), and fold changes for seeds were determined by comparing the gene expression of $21 \mathrm{~d} C+2 \mathrm{~d}$ A seeds to $1 \mathrm{~d} C$ seeds ('21d $C+2 \mathrm{~d} A$ to $1 \mathrm{~d} C^{\prime}$ ). Common genes were then identified between buds and seeds. The Arabidopsis Information Resource (TAIR) IDs represent Arabidopsis genes used to annotate homologues of leafy spurge transcripts. Unpaired two-sample t-tests were performed; symbol "*" represents genes at a p-value $<0.1$, and "**" represents genes at a $p$-value $<0.05$.

of dormancy in buds and seeds. These genes are listed (in red) in Additional file 3: Table S3. A flowering gene, $M A F 3$, was strongly up-regulated (773-fold) in ecodormant buds relative to endodormant buds (Additional file 3: Table S3, 'Eco to Endo'), and was undetectable in paradormant and growth-induced buds. In contrast, it was down-regulated (-15-fold) in germinating relative to dormant seeds (Additional file 3: Table S3, '21d C $+2 \mathrm{~d}$ A to 1d C'). In Arabidopsis, MAF3 is down-regulated by longterm cold and is involved in inhibiting flowering by directly repressing the expression of florigen $F T$ [32]. However, MAF3 expression in leafy spurge buds appears opposite based on what is observed for this gene in Arabidopsis [33]. The fact that MAF3 expression is down-regulated during seed germination and is down-regulated in growing buds relative to ecodormant buds suggest perhaps that MAF3 is a negative regulator of growth. In poplar, FT is a positive regulator of growth [34] and in Arabidopsis, MAF3 inhibits FT expression, our observation would be consistence with this hypothesis.

\section{Conclusion}

We compared transcript profiles in buds and seeds. Direct comparisons of qRT-PCR results were impractical due to intrinsic differences between buds and seeds. Therefore, we utilized two common baselines, endodormant bud and dormant seed samples, to compare and determine differentially-expressed genes. Genes responsive to dormancy states were then identified by comparing those differentially-expressed genes in buds and seeds. This approach helped identify common processes related to similar physiological states in leafy spurge crown buds and seeds. Based on the number of common genes identified and those showing the same trend in expression pattern, we conclude that physiological relatedness in some phases of dormancy and growth does exist between buds and seeds. These identified genes can be used as molecular markers for specific dormancy phases in both buds and seeds. Transcriptome analysis identified potentially important molecular mechanisms involved in dormancy induction and release. Based on the combined results, common molecular mechanisms involved in dormancy transitions of buds and seeds likely involve processes associated with $\mathrm{ABA}$ and auxin signaling and transport, cell cycle, and AP2/ERF transcription factors or their up-stream regulators. However, transcript abundance may not reflect a direct association with protein level and activity. Therefore, direct protein or hormone measurement would corroborate current results.

\section{Methods}

\section{Plant material and germination}

Leafy spurge buds were prepared according to Doğramacı et al. $[14,15]$ (Figure 2). Briefly, leafy spurge plants were propagated from the uniform biotype (1984-ND001) and maintained in a greenhouse as described by Anderson and Davis [35]. Prior to the start of each experiment, plants were acclimated in a Conviron growth chamber (Model PGR15) for 1 week at $27^{\circ} \mathrm{C}, 16: 8 \mathrm{~h}$ light:dark photoperiod. Each experiment was replicated three times, and each replicate contained 30 plants. Six plants from each replicate were used to determine vegetative growth rate, and crown buds from the remaining 24 plants were collected for qRT-PCR studies. All samples were collected between 11:00 a.m. and 1:00 p.m. central standard time to avoid diurnal variation. To induce growth, paradormant plants were decapitated and grown for 2 days at $27^{\circ} \mathrm{C}, 16: 8 \mathrm{~h}$ light:dark photoperiod. To induce endodormancy, paradormant plants were subjected to a ramp-down in temperature $\left(27 \rightarrow 10^{\circ} \mathrm{C}\right)$ and photoperiod $(16 \mathrm{~h} \rightarrow 8 \mathrm{~h}$ 
light) for 12 weeks (i.e., $R D_{\text {tp }}$ ). To induce crown buds from endo- to ecodormancy, plants subjected to the $\mathrm{RD}_{\mathrm{tp}}$ treatment were given extended cold treatment for 11 weeks at $5-7^{\circ} \mathrm{C}$, under constant 8 h:16 h light:dark cycle. A set of paradormant plants was kept under constant temperature and photoperiod $\left(27^{\circ} \mathrm{C}, 16 \mathrm{~h}\right.$ light) as a control. Endodormant buds were used as the baseline for transcriptome comparisons.

Field-grown leafy spurge seeds were collected from Fargo, ND USA in 2006, 2007, and 2008. Seed harvesting, drying, fractionation, storage, surface disinfection, imbibition in water, and germination were previously described $[7,8]$. In this study, three germination treatments (Figure 3) were subjected to qRT-PCR analysis: I) 1d C: seeds imbibed for 1 $\mathrm{d}$ at the constant temperature of $20^{\circ} \mathrm{C} .1 \mathrm{~d} \mathrm{C}$ seeds were used as the baseline for transcriptome comparisons; II) 21d C: seeds imbibed for $21 \mathrm{~d}$ at the constant temperature of $20^{\circ} \mathrm{C}$. III) $21 \mathrm{~d} \mathrm{C}+2 \mathrm{~d}$ A: seeds imbibed for $21 \mathrm{~d}$ at $20^{\circ} \mathrm{C}$ followed by $2 \mathrm{~d}$ at the alternating temperature $\left(20: 30^{\circ} \mathrm{C} / 16: 8 \mathrm{~h}\right)$. Seeds were kept in the dark, except for short period of rating and harvesting seeds. The 2006, 2007, and 2008 seed samples served as the biological replicates.

\section{qRT-PCR}

Primer pairs (20-24 nucleotides) were designed using Lasergene (DNASTAR, Inc., Madison, WI) sequence analysis software from 201 clones annotated to genes based on sequences obtained from a leafy spurge EST-database [36]. Gene abbreviations and descriptions of all putative homologous leafy spurge genes (Additional file 1: Table S1) were obtained from an Arabidopsis website (www.arabidopsis. org). The details of cDNA preparation and qRT-PCR parameters were described previously by Chao [37]. Briefly, the comparative CT method was used to determine changes in target gene expression in test samples relative to a control sample. Fold difference in gene expression of test vs. control sample is $2^{-\Delta \Delta C T}$, where $\Delta \Delta C_{T}=\Delta C_{T, \text { test }}-\Delta C_{T}$, control. Here, $\Delta C_{T, \text { test }}$ is the $C_{T}$ value of test sample normalized to the endogenous reference gene, and $\Delta \mathrm{C}_{\mathrm{T} \text {,control }}$ is the $C_{T}$ value of the control normalized to the same endogenous reference gene. SYBR green chemistry was used to produce fluorescent signal, and three technical replicates were used per sample for the qRT-PCR experiments. The $C_{T}$ value of each gene is the average of three technique replicates. A leafy spurge SAND family gene was used as a reference; this gene was verified to be stably expressed during seed and bud development [38]. Values from three biological replicates were averaged, and data from $1 \mathrm{~d} C$ seeds and endodormant buds were used for baseline expression. QbasePLUS version 2.4 software (Biogazelle, Ghent, Belgium) was used to normalize expression values and to perform statistical analyses. The difference in gene expression is designated as $\log 2$ and fold value (see Additional file 3: Table S3 for these two values).

\section{Cluster analysis and $t$-test}

Transcript expression intensities were $\log 2$ transformed, and normalized with SAND family gene. Cluster analysis is done to group expression similarities of 201 genes in different phases of bud and seed samples. Euclidean distance (linear scaled) method and UPGMA clustering algorithm were used in this analysis. To identify genes with significant differential expression between two different phases of dormancy, unpaired two-sample t-tests were performed and genes at a $\mathrm{p}$-value $<0.1$ are considered as statistically significant.

\section{Additional files}

Additional file 1: Table S1. Gene abbreviations/descriptions and primer pair sequences.

Additional file 2: Table S2. Melting point temperatures and DNA bands for 201 amplicons.

Additional file 3: Table S3. Differentially-expressed genes within buds and seeds for the 201 genes by qRT-PCR.

\section{Competing interest}

The authors declare no competing interests.

\section{Authors' contributions}

WSC, MD, JVA, MEF, and DPH conceived and designed the experiments. WSC and $M D$ performed the experiments and analyzed the data. WSC wrote the paper. WSC, MD, JVA, MEF, and DPH revised and approved the final manuscript.

\section{Acknowledgements}

The authors thank to Wayne A. Sargent and Cheryl A. Huckle and for their technical assistance.

Received: 29 May 2014 Accepted: 4 August 2014

Published: 12 August 2014

\section{References}

1. Leitch JA, Leistritz FL, Bangsund DA: Economic effect of leafy spurge in the Upper Great Plains: methods, models, and results. Impact Assess 1996, 14:419-433.

2. Bewley JD: Seed germination and dormancy. Plant Cell 1997, 9:1055-1066.

3. Baskin JM, Baskin CC: A classification system for seed dormancy. Seed SCi Res 2004, 14:1-16.

4. Nikolaeva MG: On criteria to use in studies of seed evolution. Seed Sci Res 2004, 14:315-320.

5. Finch-Savage WE, Leubner-Metzger G: Seed dormancy and the control of germination. New Phytol 2006, 171:501-523.

6. Bowes CG, Thomas AG: Longevity of leafy spurge seeds in the soil following various control programs. J Range Manage 1978, 31:137-140.

7. Foley ME, Chao WS: Temperature and moisture status affect afterripening of leafy spurge (Euphorbia esula) seeds. Weed Sci 2008, 56:516-522.

8. Foley ME, Anderson JV, Chao WS, Horvath DP: Initial changes in the transcriptome of Euphorbia esula seeds induced to germinate with a combination of constant and diurnal alternating temperatures. Plant $\mathrm{Mol}$ Biol 2010, 73:131-142.

9. Lang GA, Early JD, Martin GC, Darnell RL: Endo-, para-, and ecodormancy: physiological terminology and classification for dormancy research. HortScience 1987, 22:371-377.

10. Horvath DP: The role of specific plant organs and polar auxin transport in correlative inhibition of leafy spurge (Euphorbia esula) root buds. Can J Bot 1998, 76:1227-1231.

11. Horvath DP: Role of mature leaves in inhibition of root bud growth in Euphorbia esula L. Weed Sci 1999, 47:544-550. 
12. Chao WS, Serpe MD, Anderson JV, Gesch RW, Horvath DP: Sugars, hormones, and environment affect the dormancy status in underground adventitious buds of leafy spurge (Euphorbia esula L.). Weed Sci 2006, 54:59-68.

13. Anderson JV, Gesch RW, Jia Y, Chao WS, Horvath DP: Seasonal shifts in dormancy status, carbohydrate metabolism, and related gene expression in crown buds of leafy spurge. Plant Cell Environ 2005, 28:1567-1578.

14. Doğramacı M, Horvath DP, Chao WS, Foley ME, Christoffers MJ, Anderson JV: Low temperatures impact dormancy status, flowering competence, and transcript profiles in crown buds of leafy spurge. Plant Mol Biol 2010, 73:207-226.

15. Doğramacı M, Foley ME, Chao WS, Christoffers MJ, Anderson JV: Induction of endodormancy in crown buds of leafy spurge (Euphorbia esula L.) implicates a role for ethylene and cross-talk between photoperiod and temperature. Plant Mol Biol 2013, 81:577-593.

16. Powell LE: Hormonal aspects of bud and seed dormancy in temperate-zone woody plants. HortScience 1987, 22:845-850.

17. Dennis FG Jr: A Physiological Comparison of Seed and bud Dormancy. In Plant Dormancy: Physiology, Biochemistry and Molecular Biology. Edited by Lang GA. Wallingford: CAB International; 1996:47-56.

18. Pasternak G, Powell LE: Chilling requirements of apple seeds from cultivars having low and high chilling requirements for shoot growth. HortScience 1980, 15:408.

19. Leida C, Conejero A, Arbona V, Gómez-Cadenas A, Llácer G, Badenes ML, Ríos G: Chilling-dependent release of seed and bud dormancy in peach associates to common changes in gene expression. PLoS One 2012, 7:e35777. doi:10.1371/journal.pone.0035777.

20. Ruttink T, Arend M, Morreel K, Storme V, Rombauts S, Fromm J, Bhalerao RP, Boerjan W, Rohde A: A molecular timetable for apical bud formation and dormancy induction in poplar. Plant Cell 2007, 19:2370-2390.

21. Chao WS, Foley ME, Doğramacı M, Anderson JV, Horvath DP: Alternating temperature breaks dormancy in leafy spurge seeds and impacts signaling networks associated with HY5. Funct Integr Genomics 2011, 11:637-649.

22. Horvath DP, Sung S, Kim D, Chao WS, Anderson JV: Characterization, expression and function of Dormancy Associated MADS-Box genes from leafy spurge. Plant Mol Biol 2010, 73:169-179.

23. Integrated DNA Technologies, Inc: Interpreting melt curves: an indicator, not a diagnosis. http://www.idtdna.com/pages/decoded/decoded-articles/ core-concepts/decoded/2014/01/20/interpreting-melt-curves-an-indicator-nota-diagnosis. Accessed 23 May 2014.

24. Xiong $L$, Lee $H$, Ishitani M, Zhu JK: Regulation of osmotic stress-responsive gene expression by the LOS6/ABA1 locus in Arabidopsis. J Biol Chem 2002, 277:8588-8596.

25. Geisler M, Murphy AS: The ABC of auxin transport: the role of p-glycoproteins in plant development. FEBS Lett 2006, 580:1094-1102.

26. Leyser O: Molecular genetics of auxin signaling. Annu Rev Plant Biol 2002, 53:377-398

27. Pierre-Jerome $\mathrm{E}$, Moss $B L$, Nemhauser $J$ : Tuning the auxin transcriptional response. J Exp Bot 2013, 64:2557-2563.

28. Vicient C, Hull G, Guilleminot J, Devic M, Delseny M: Differential expression of the Arabidopsis genes coding for Em-like proteins. J Exp Bot 2000, 51:1211-1220

29. Rakusová H, Gallego-Bartolomé J, Vanstraelen M, Robert HS, Alabadí D, Blázquez MA, Benková E, Friml J: Polarization of PIN3-dependent auxin transport for hypocotyl gravitropic response in Arabidopsis thaliana. Plant J 2011, 67:817-826.

30. Cosgrove DJ: Growth of the plant cell wall. Nat Rev Mol Cell Biol 2005 6:850-861.

31. Goh H-H, Sloan J, Dorca-Fornell C, Fleming A: Inducible repression of multiple expansin genes leads to growth suppression during leaf development. Plant Physiol 2012, 159:1759-1770.

32. Gu X, Le C, Wang Y, Li Z, Jiang D, Wang Y, He Y: Arabidopsis FLC clade members form flowering-repressor complexes coordinating responses to endogenous and environmental cues. Nat Commun 2013, 4:1947. doi: 10.1038/ncomms2947.

33. Ratcliffe OJ, Kuminoto RW, Wong BJ, Riechmann JL: Analysis of the Arabidopsis MADS AFFECTING FLOWERING gene family: MAF2 prevents vernalization by short periods of cold. Plant Cell 2003, 15:1159-1169.

34. Hsu CY, Adams JP, Kim H, No K, Ma C, Strauss SH, Drnevich J, Vandervelde L, Ellis JD, Rice BM, et al: FLOWERING LOCUS T duplication coordinates reproductive and vegetative growth in perennial poplar. Proc Natl Acad Sci U S A 2011, 108:10756-10761.

35. Anderson JV, Davis DG: Abiotic stress alters transcript profiles and activity of glutathione S-transferase, glutathione peroxidase, and glutathione reductase in Euphorbia esula. Physiol Plant 2004, 120:421-433.

36. Anderson JV, Horvath DP, Chao WS, Foley ME, Hernandez AG, Thimmapuram J, Liu L, Gong GL, Band M, Kim R, Mikel MA:

Characterization of an EST database for the perennial weed leafy spurge: an important resource for weed biology research. Weed Sci 2007, 55:193-203.

37. Chao WS: Real-time PCR as a tool to study weed biology. Weed Sci 2008 56:290-296

38. Chao WS, Doğramaci M, Foley ME, Horvath DP, Anderson JV: Selection and validation of endogenous reference genes for qRT-PCR analysis in leafy spurge (Euphorbia esula). PLoS One 2012, 7:e42839. doi:10.1371/journal. pone.0042839.

\section{doi:10.1186/s12870-014-0216-4}

Cite this article as: Chao et al:: The resemblance and disparity of gene expression in dormant and non-dormant seeds and crown buds of leafy spurge (Euphorbia esula). BMC Plant Biology 2014 14:216.

\section{Submit your next manuscript to BioMed Central and take full advantage of:}

- Convenient online submission

- Thorough peer review

- No space constraints or color figure charges

- Immediate publication on acceptance

- Inclusion in PubMed, CAS, Scopus and Google Scholar

- Research which is freely available for redistribution

Submit your manuscript at www.biomedcentral.com/submit

C BioMed Central 